This item was submitted to Loughborough's Research Repository by the author.

Items in Figshare are protected by copyright, with all rights reserved, unless otherwise indicated.

\title{
The myth of Kurt Lewin and the rhetoric of collective memory in social psychology textbooks
}

PLEASE CITE THE PUBLISHED VERSION

http://dx.doi.org/10.1177/0959354315594255

PUBLISHER

SAGE Publications

VERSION

AM (Accepted Manuscript)

\section{PUBLISHER STATEMENT}

This work is made available according to the conditions of the Creative Commons Attribution-NonCommercialNoDerivatives 4.0 International (CC BY-NC-ND 4.0) licence. Full details of this licence are available at: https://creativecommons.org/licenses/by-nc-nd/4.0/

\section{LICENCE}

CC BY-NC-ND 4.0

\section{REPOSITORY RECORD}

Billig, Michael. 2019. "The Myth of Kurt Lewin and the Rhetoric of Collective Memory in Social Psychology Textbooks”. figshare. https://hdl.handle.net/2134/18179. 
The myth of Kurt Lewin and the rhetoric of collective memory in social psychology textbooks

Michael Billig

Department of Social Sciences

Loughborough University

To appear: Theory \& Psychology 


\begin{abstract}
This paper examines how social psychology textbooks represent Kurt Lewin and his contribution to social psychology. Many textbooks describe Lewin as the father of social psychology, using a conventional, passive voiced trope to do so. The rhetorical meaning of this trope is analysed to show that textbooks are invoking a collective memory, which closes down views of the past, rather than making a historical argument, which opens up the past for examination. This depiction of Lewin typically involves forgetting his critical views about statistics and experimentation. When textbooks cite Lewin's famous motto "there is nothing as practical as a good theory", they tend to ascribe it a special status. In doing so, they change its meaning subtly and treat it as a truth that needs no empirical validation. By their rhetoric, omissions and avoidance of historical sources, textbooks recreate Lewin as a mythic figure rather than a historical one.
\end{abstract}

Keywords: Kurt Lewin, collective memory, social psychology textbooks, history of social psychology 
Recently a number of analysts have been showing a critical interest in social psychology textbooks. Lubek (1993 and 2000) has argued that social psychology textbooks typically fulfil a conservative function by training students to accept the dominant assumptions of the discipline. Accordingly, studies have shown how textbooks promote the values of experimentalism, while marginalising or completely ignoring other perspectives (e.g. Billig, 2013, chapter seven; Lubek, 1993; MacMartin and Winston, 2000; Stam, Lubek and Radtke, 1998; Stam, Radtke and Lubek, 2000). As Gordon Allport (1954) realized many years ago, textbooks can reveal the changing patterns of social psychology over time. Thus, historical analyses of textbooks show how and when experimentalism became social psychology’s dominant trend (e.g. Danziger, 2000; MacMartin and Winston, 2000; Stam et al, 2000). As well as examining historical changes within textbooks, it is also possible to examine how textbooks depict the history of social psychology (Delouvée, Kalampalikis and Pétard, 2011; Kalampalikis, Delouvée and Pétard, 2006; Pétard, Kalampalikis and Delouvée, 2001). This topic is particularly interesting because it has been suggested that experimental psychologists and historians view human behaviour in opposing ways: experimental psychologists supposedly search for universal laws of behaviour, while historians analyse particular events; and experimentalists view historians as backward looking and unscientific, while seeing themselves as forward looking scientists (see inter alia, Danziger, 2000; Gergen, 2001; Tileagă and Byford, 2014).

Pétard, et al (2001), studying trends in social psychology textbooks published in French between 1946 and 2001, show that there has been a decline in the proportional amount of space that textbooks allot to the history of their discipline. Nowadays, it is rare for major English language textbooks to devote an entire chapter to social psychology’s past. Some books include very brief sub-sections on history in their opening chapter: Taylor, Peplau and Sears (2006) have a one page sub-section while Crisp and Turner 
(2014) devote two pages to theirs. Other major textbooks have no sub-sections on the history of the discipline (e.g., Myers, 2008; Gilovich, Keltner and Nisbett, 2011; Bordens and Horowitz, 2014). Of course, such texts may refer to social psychology's past, but they will do so in the context of discussing specific contemporary topics.

In their corpus of French language textbooks Delouvée et al (2011) found that Kurt Lewin was one of the most cited historical social psychologists and that over time he has become increasingly identified as the father/founder of social psychology. This depiction of Lewin is, according to Delouvée et al (2011), somewhat paradoxical. The earlier postwar textbooks discussed Lewin's research at length but did not call him social psychology's father/founder. By contrast, many of today’s textbooks identify Lewin as the father/founder but do not discuss his research.

The present paper aims to investigate this paradox further, by exploring how English language textbooks today refer to Lewin. This means taking selected examples from textbooks and examining their meaning and rhetorical composition in detail. There are a number of reasons why the detailed analysis of selected examples is appropriate. If history represents what Stam et al (2000) call an area of ‘strain', then claiming Lewin to be the discipline's founder/father might avoid this strain while simplifying the discipline’s complex heritage which histories of social psychology stress (Billig, 2008a; Danziger, 2000; Farr, 1996; Jahoda, 2013; Moscovici and Marková, 2006; Pandora, 1997). It would also involve forgetting that Lewin strongly criticised the sorts of experimental and statistical analyses that are now standard within social psychology (Ash, 1998; Billig, in press; Danziger, 1994). Lewin (1938) advocated that psychologists should study concrete examples in depth, rather than collect and statistically analyse multiple examples of the same phenomenon. By analysing particular examples from the textbooks rather than 
compiling averaged trends from a wider corpus, the present study conforms in this small regard to Lewin's own methodological preferences.

It will be useful to follow a distinction which some specialists in memory studies, following the pioneering work of Maurice Halbwachs, make between history as an academic discipline and the collective memory of social groups (e.g., Halbwachs, 1992; Erll, 2011; Olick, 2007). History, it is said, opens up the past to debate while collective memory produces closed, simplified accounts, often designed to serve the present concerns of a group. Examples of textbooks mentioning Lewin and his place in social psychology's past will be analysed to see whether the writers appeal to the works of historians or to the collective common sense of the discipline. This will involve noting discursive absences as well as presences because what is routinely forgotten can be as significant as what is remembered (Erll, 2011; Middleton and Brown, 2005).

\section{$\underline{\text { Science and Common Sense }}$}

Current social psychology textbooks might not treat the history of their discipline as particularly important, but in their opening chapters they foreground the message that social psychology is a science. They often contrast the science of social psychology with unscientific common sense (Billig, 2013). This contrast forms the background against which specific references to Lewin should be understood.

It is easy to find examples of textbooks giving early prominence to the claim that social psychology is a science. On the second page of chapter one Sanderson (2010) describes social psychology as a "scientific study”, as do Bordens and Horowitz (2014), while Myers (2008) uses the same description on the third page. Hogg and Vaughan (2011) include a description of social psychology as a "scientific investigation" in the 
opening sentence of their first chapter. Baron and Branscombe (2013) manage to convey the message even earlier: the title of their opening chapter is "Social psychology: the science of the social side of life". Textbooks in the natural sciences tend not to emphasise their scientific credentials in this way; their readers are presumed to know that they are reading about a science (Billig, 2013).

In claiming social psychology to be a science and comparing it with unscientific common sense, the textbooks are making value-laden judgements. Chapter one in Sanderson (2010) contains a section entitled “Is Social Psychology Really Just Common Sense?” The author emphatically answers in the negative. Baron and Branscombe (2013) claim that we should be "suspicious of common sense”, which unlike social psychological research presents a "confusing and inconsistent picture of human behaviour” (pp. 14-5). Crisp and Turner (2014) suggest that we need social psychology to "provide scientific tests of what people believe is common sense, and to debunk misperceptions” (p. 2). According to Gilovich et al (2011), “stories and parables have attempted to explain human behaviour for millennia” but social psychologists "go beyond folk wisdom and try to establish a scientific basic for understanding human behaviour” (p. 7).

In the history of European thought, the term "common sense” has had two principal meanings: the sensus communis or the commonly shared sense of a particular community or of ordinary people in general; and common sense as good sense, or le bon sens (Rosenfeld, 2011). When social psychology textbooks contrast scientific social psychology favourably with "common sense”, they are generally using the latter term to mean the commonly shared sense of ordinary people. The textbooks claim that it is not good sense to accept this common sense. Good sense should be based on scientific research into those topics about which ordinary people supposedly hold ill-informed, confused opinions. 
Since "folk wisdom" includes beliefs about the past, we can ask whether the textbooks also advocate replacing shared collective memories of the past with evidencebased, historical knowledge; and whether this includes the common opinions which professional social psychologists might share about their discipline’s past.

\section{The common trope}

When textbooks describe Lewin as a/the father/founder of social psychology, they often use a particular trope. Hogg and Vaughan (2011) state: "Lewin is generally considered the father of experimental social psychology" (p. 21); later they suggest that Lewin is "often referred to as the father of experimental social psychology” (p. 43). Sanderson (2010), having listed several Gestalt psychologists, then writes: "One of these psychologists, Kurt Lewin, is often considered to be the founder of modern social psychology” (p. 9). StaintonRogers (2007) uses similar wording: “Lewin is generally considered the 'founding father' of experimental social psychology" (p. 20). Not all textbooks use the "considered to be" trope. Gilovich et al (2011) directly identify Lewin as "the founder of modern social psychology” (p. 11), while Baron and Branscombe (2010, p. 103) and Aronson, Wilson and Akert (2010, p. 72) more cautiously describe Lewin as “one of the founders of modern social psychology” (without identifying who the other founders might be). And some textbooks do not mention Lewin at all (e.g., Crisp and Turner, 2014).

The distinguishing feature of the trope is its indirectness, accomplished by using a verb such as "consider" in the passive voice. The trope can also be found in handbooks and research papers. Taylor (1998) writing in the fourth edition of the Handbook of social psychology states: "The father of modern social psychology is generally acknowledged to be Kurt Lewin” (p. 60). In Oxford handbook of contextual political analysis McGraw (2006) claims that Lewin "is widely recognized as the father of modern social psychology" 
(p. 133). Kaminski (2011, para.2) in Canadian Journal of Nursing Informatics uses the trope twice: Kurt Lewin "has been acknowledged as the 'father of social change theories'” and Lewin "is also lauded as the originator of social psychology, action research, as well as organizational development.” Whether writers use “considered”, “acknowledged” or "lauded" there is the same indirectness: the authors do not identify who is doing the considering, acknowledging or lauding.

Academic writers use the trope about other figures and other disciplines. For example, Skidelsky (2009) writes that Simmel "is now acknowledged...as a founding father of German sociology (p. 173). According to Elliott (2008), George Herbert Mead “is widely considered the founding father of a general tradition of theoretical thinking concerned with the self: symbolic interactionism” (p. 30). Pelly (2006) claims that Lester Ward, the first president of the American Sociological Association, “is known as 'the Father of American Sociology' (2006, p. 209).

It is easy to see why academic writers might favour such indirectness for academics commonly hedge statements, thereby leaving themselves an escape route in the event of a challenge (Biber and Gray, 2010; Hyland, 2005 and 2009). Although the trope might be hedged it can convey a similar message to an unhedged assertion. Some writers, in fact, move between hedged trope and direct statement. Within the space of two pages Sanderson (2010) goes from claiming that "Kurt Lewin...is often considered the founder of social psychology" (p. 9) to the direct ascription: "Kurt Lewin, the founder of modern social psychology” (p. 11; see also Aronson et al, 2010, who use the direct ascription on p. 72 and the indirect trope on p. 461). This suggests that writers might be using the trope as a conventionally hedged way of conveying $\mathrm{X}$ to be the founder of $\mathrm{Y}$. 
Academic textbooks may not contain as many hedged statements as research papers, but they still contain a higher proportion than most non-academic writing (Biber and Conrad, 2009; Biber, Conrad and Cortes, 2004). One may conjecture that the further one gets from academic writing, the less likely one is to find the trope. Pelly (2006) might have hedged the claim about Lester Ward being the father of American sociology but there is no hedging on the sign erected in Bradford County, Pennsylvania, marking Ward’s birthplace: "Lester Frank Ward: Father of American Sociology” (Rafferty, 2003, p. 2).

At this point, some readers might think that the use of the trope in social psychology textbooks has been adequately explained. The textbooks writers are merely using conventional academic wording to describe Kurt Lewin’s special status within social psychology. This is hardly surprising because textbook writers are themselves academics. However, that is not the end of the matter. As will be argued, this use of the trope in social psychology textbooks contains features that directly relate to the distinction between collective memory and history.

\section{The trope and common sense}

To understand the significance of the trope, it is necessary to examine what writers can avoid specifying by its use. Critical linguists have noted that the passive voice enables writers to be vague about who is performing actions (Billig, 2008b; Fowler, 1991; Fowler, Hodge, Kress and Trew, 1979). Scientific writers favour the passive voice in the methods sections of papers, in order to convey that the identity of the researcher conducting the study was irrelevant to the obtained results (Biber and Conrad, 2009). When social scientists more generally use the passive voice to describe social actions, they can spare 
themselves the trouble of describing precisely who is acting and how they might be acting (Billig, 2008b and 2013).

The trope may refer to people believing, considering, recognizing someone to be a disciplinary founder/father but by using the passive voice writers need not specify who those people are. If writers had used the active voice, then they would have needed to provide a grammatical subject to identify who was considering Lewin to be the founder/father of social psychology. Even when writers qualify the trope by adding 'generally' or 'often', they avoid saying who may not agree with the judgment, nor most crucially why they might disagree. By this absence they are conveying the judgment to be universal or virtually universal.

However, the judgment cannot be literally universal for the writers are not presuming that their readers already know about Lewin. They sometimes repeat the judgment. This would be doubly unnecessary, if they believed that Lewin's founding of social psychology was part of general common sense. The writers are assuming that their student readers are not members of the community that considers Lewin to be the father/founder. Even if the writers implicitly associate themselves with the judgment of this unnamed community, they give no grammatical indication. For example, they do not write that "we consider Lewin to be our father/founder", using the first person plural as Levine (2008) did in the introduction to Journeys in social psychology, a book which brought together a distinguished group of largely American, experimental social psychologists to reflect on the development of their discipline. Levine wrote that "we study the give and take between individuals and the environments that guide their behaviour, what our founding father Kurt Lewin called 'the life space”” (p. ix).

Nevertheless, the textbook writers manage to imply some sort of affiliation without using the first person. The group that considers Lewin to be social psychology’s 
founder/father is, by implication, a group that is competent to make such a judgment. It is not a group of bio-chemists, undergraduates or residents of Bradford County. The group is presumed to be professional social psychologists. By using the trope uncritically, the textbook writers are implying that their readers should accept this judgement. Since the textbook writers are themselves social psychologists, their position is effectively the same as Levine's openly stated position: they might imply that Lewin is our founding father but by their grammar they avoid expressing open partiality.

If we take note of a significant absence, we can see that the judgement contained within the trope is based on an assumed collective memory, not historical judgement. Smyth (2001) has shown that psychology textbooks are rich in references, especially when compared with textbooks in the natural sciences. When discussing the findings of empirical studies, social psychology textbooks cite sources, but when it comes to judgements about the discipline's past, then referencing all but disappears. In stating that Lewin is (generally) considered to be the father/founder, textbook writers do not support the claim with references to empirical studies of social psychologists' opinions about the father/founder of their discipline. Nor are there references to historical studies.

Instead the judgment stands within a small oasis of reference-free prose. Because the judgement is not referenced as the judgment of historians, it is implicitly presented as the shared sense of the community that is being represented by the textbook. Thus, textbook writers convey that it is good sense to accept this commonly held judgment about the discipline's past.

\section{Common sense simplifying history}


The common sense, which the trope tacitly assumes, is part of the disciplinary common sense of social psychology - or to be more precise the disciplinary common sense held by the sort of experimental social psychologists represented by Levine (2008). By considering Lewin to be the founder/father, the holders of this common sense assume Lewin to have been an experimentalist, producing the sort of work that anticipated the empirical investigations that have become common within mainstream social psychology. A number of omissions and simplifications suggest that this is a judgement of disciplinary common sense rather than disciplinary history.

First, there are questions that textbooks tend not to pose: in what respect was Lewin the father/founder of (modern) social psychology and what did do to qualify for that title? The textbooks, especially those with historical sub-sections, often describe Triplett as having conducted the first experiment in social psychology in 1898. Gilovich et al (2011) use the passive trope: Triplett’s study is “widely regarded as social psychology’s first experiment” (p. 536), as if being “widely” held makes a belief more trustworthy. The first edition of Journeys in social psychology, which contained a narrower band of contributors than the second edition, grew out of a meeting to mark the centenary of Triplett's experiment. However, studies into the origins of experimental social psychology throw doubt on whether Triplett's study was actually the first social psychological experiment (Haines and Vaughan, 1979; Danziger, 2000). The issue here is not to identify the first experiment, but to note that textbook writers can identify Lewin as the founder/father of social psychology while also claiming a much earlier experiment to be the first in social psychology.

Historians have no difficulty in explaining the apparent contradiction. Danziger (2000) argues that founding a discipline like social psychology involves much more than conducting the first experiment that later comes to be called social psychological. 
However, the textbook writers generally do not discuss exactly why Lewin might merit the title of founder/father. Rather unusually Stroebe, Hewstone and Jonas (2013) do mention the difficulty and suggest that Lewin influenced social psychology by inspiring his research students rather than by his own empirical work which is not widely cited today. Sometimes, the textbooks are somewhat vague about what they are attributing to Lewin. Gilovich et al (2011), having described Lewin as "the founder of modern social psychology” (p. 11), describe him on the following page as “a pioneer in social psychology" (p. 12). The authors do not explain the difference between being "the founder” and being “a pioneer”. It is as if such historical niceties do not matter. Gilovich et al (2011) have a fifty-four page reference list, but their brief discussion of Lewin does not refer to a single history of social psychology. The fifty-four page reference list does not include the main histories of the discipline. Thus, the textbook directs students towards first hand reports of empirical studies in social psychology; but to understand the past, readers have to rely on collective memories within the disciplinary common sense that the textbook is transmitting.

This collective memory is not always trustworthy. Gilovich et al (2011) describe Lewin as a "physicist before becoming a psychologist" (p. 11). This is inaccurate: Lewin studied philosophy as an undergraduate (Marrow, 1969). Hogg and Abrams (1988, p. 8) also wrongly ascribe a background in physics to Lewin ("the father of modern experimental social psychology"), while also wrongly describing Wundt ("the father of experimental psychology”) as having trained as a physicist; they do not cite any sources on Wundt's or Lewin's lives. Hogg and Abrams were using the examples of Lewin and Wundt as part of an argument that social psychology was scientific by virtue of its methods. If experimental psychology and experimental social psychology were founded by proper natural scientists, then this strengthens present claims of scientific status. The 
authors are in effect constructing a desired disciplinary memory to support present positions and they do so by overlooking historical studies.

Most of the histories of modern social psychology stress that Lewin did not, and indeed could not, have single-handedly founded social psychology. Social psychology already existed as a sub-disciplinary entity in the United States before Lewin’s famous studies, as is evidenced by the first and second editions of the book Experimental social psychology (Murphy and Murphy, 1931; Murphy, Murphy and Newcomb, 1937). To make Lewin the founder/father is to diminish the roles of Floyd and Gordon Allport, whose contributions to founding the discipline are emphasised within historical studies (Danziger, 2000; Farr, 1996; Moscovici and Marková, 2006; Pandora, 1997). In fact, Daniel Katz (1979) declared that "Floyd Allport was the father of experimental social psychology" (p. 351).

Those textbooks that identify Lewin as founder/father tend not to give much, if any, space to alternative views of social psychology or its history. Moreover, textbook writers tend not to draw attention to the gaps in Lewin’s legacy. Most have chapters outlining the research into attitudes. According to Hogg and Vaughan (2011) attitudes "remain a key, if sometimes controversial, part of social psychology” (p. 149). This textbook, like others, does not mention that the figure considered to be the father/founder of the discipline resisted using the key disciplinary terms of “attitude”, as Gordon Allport (1948) made clear in his generous obituary of Lewin.

We can ask what else the collective memory of the discipline might be overlooking. The biggest simplification is the way that Lewin is recruited as if he were patron of current experimental ways of doing social psychology. The mainstream textbooks are filled with descriptions of experimental studies in which variables are tightly controlled in order to isolate specific effects. Hogg and Vaughan (2011) in their opening chapter write that social 
psychology “is largely experimental” because most social psychologists “would prefer to test hypotheses experimentally if at all possible” (p. 9). They then describe a hypothetical social psychology experiment. It is a tightly controlled study with twenty children randomly assigned to two conditions where they either watch a violent or a non-violent programme. All else is controlled. The problem is that this is just the sort of experimental investigation that Lewin explicitly criticised as ‘Aristotleian’ (Lewin, 1931/1999). He preferred to examine concrete, individual situations in which groups or individuals would organically develop new patterns of action over time (Lewin, 1938; see Billig, in press).

In addition, the founder/father criticised the practice of running separate trials for each condition (i.e. ten children watching aggressive programmes and ten watching nonaggressive ones) and then statistically comparing the averaged data from the conditions. Lewin strongly argued that statistics belonged to the Aristoteleian or pre-modern stage of science (Lewin, 1931/1999 and 1938). He aspired to a science in which mathematics especially geometry would be used for exploring qualitative, not quantitative, differences. From the textbooks one would not suspect that Lewin disapproved of the procedures that have now become standard. Gilovich et al (2011) write of the importance of statistical analyses: "We will not mention the concept of statistical significance again because all of the findings we report in this book are statistically significant” (p. 59). It is just as well that they do not discuss Lewin’s empirical studies. Curiously, Gilovich et al include Lewin’s 1931 article criticising Aristotelian (statistical) methods in their reference list, but do not refer to it in the text. It is as if the memory of Lewin's views has been textually repressed but returns as a bibliographic reference to haunt the disciplinary consciousness. However, few readers will notice the reference, detached from any connection with the text.

Gilovich et al (2011) and other textbooks, which briefly pay tribute to the founder/father, do not refer to historians or other scholars who have outlined Lewin's 
controversial views on science and who have pointed to the contradiction between those views and the methodological practices that have become standard in social psychology since the 1960s. If the trope, which writers use to accord Lewin the status of founder/father, implicitly assumes the sense of a community, then its collective memory is marked by simplification and omission. We can say that more is being communally forgotten about Lewin than is being communally remembered; and much of this forgetting is communally convenient, at least for those sharing the dominant intellectual position within the disciplinary community.

\section{Nothing as practical as a good theory}

To go further, we need to examine what the textbooks tend to remember about Lewin's contribution to social psychology, given that a decreasing number of them quote his empirical studies (Delouvée et al, 2011). A good number of the textbooks, but by no means all, associate Lewin with the famous motto "there is nothing as/so practical as a good theory”. Baron and Branscombe (2013) in their only reference to Lewin write: "Kurt Lewin, one of the founders of modern social psychology, often remarked 'There's nothing as practical as a good theory’” (p. 103; see also Aronson et al, 2010, pp. $72-3$ and p. 462; Myers, 2008, p. 17).

Such textbooks tend to present the motto as occupying a special place within the disciplinary common sense. Aronson et al (2010) write: “Kurt Lewin (1951), one of the founders of social psychology, coined a phrase that has become a motto for the field: 'There is nothing so practical as a good theory”” (p. 72). In claiming that Lewin's saying has become a motto for the field, Aronson et al are pointing to its special status among members of the disciplinary community. There are two additional signs that mark out the 
motto in the textbooks as being part of the disciplinary common sense. Both these signs are absences.

Absence of reference. Unusually Aronson et al (2010) provide a referenced source for Lewin's motto: his posthumously published book Field theory in the social science (1951/1999). Usually textbook writers do not provide a source for the motto. Some by their choice of wording, together with the absence of a published source, imply that the motto comes from Lewin's spoken words. Baron and Branscombe, in the quotation already cited, write that Lewin “often remarked”. According to Myers (2008, p, 17), Lewin “declared” the motto; Hogg and Vaughan (2011, p. 29) claim that "Lewin is often quoted as saying 'there is nothing so practical as a good theory"” (emphasis added). None of these descriptions suggest that the motto might be traced to a published academic text. In this way, textbook writers can present the motto as if it belongs to a disciplinary folk memory, as the spoken words of the father/founder that have been passed down generations of social psychologists.

Aronson et al (2010) may have provided a published source for Lewin’s motto, but that does not make their description of the motto’s origins accurate. According to Aronson et al, Lewin is the originator of the motto: he "coined” the phrase. Lewin (1944, p.27) may have used the motto near the end of the article that was to become part of chapter seven in Field theory (1951/1999), but that was not the first time he used it in print. The previous year Lewin used it in a paper, and there he made clear that he had not coined the motto. He wrote: “A businessman once stated that 'there is nothing as practical as a good theory”" (1943/1999, p. 336).

Attributing the motto to a businessman alters the phrase, for it is by no means certain that a businessman (or businesswoman) would understand the terms "practical" and 
"good theory" in the same way as an academic might (Billig in press; Weick, 2003). The attribution implies that the saying, which supposedly has become the inspirational motto for social psychology, originates from outside the discipline - and from the sort of common sense which members of discipline are supposed to find unsatisfactory and which they collectively wish to replace with empirical evidence. Forgetting the businessman is linked to a wish. Taylor (1998), in a footnote to an article in Handbook of social psychology, quotes the words of Lewin (1943/1999), commenting that "students of social psychology may be chagrined to learn” that Lewin had not invented the phrase (p. 87n). Most textbooks protect their student readers from such chagrin. In her own textbook, Taylor neither mentions the motto nor cites the article in which Lewin attributes its origin to a businessman (Taylor et al, 2006). Professional social psychologists are also protected from feelings of disappointment. Lewin's attribution of the motto to a businessman has been excised from the version which is commonly quoted. In consequence, Lewin's businessman has either been collectively long forgotten or is now safely confined within a few easily overlooked footnotes.

We do not have to rely on Lewin's attribution of the motto to a businessman in order to know that he was not its originator. He was not even the first to use the motto in the context of psychology. G. Stanley Hall, the first president of the American Psychological Association, had used it in his book Youth, published in 1906. Writing of the role of ideas in moral and religious education, Hall commented that "nothing is so practical as a good theory” (Hall, 1906, p. 331). Hall also used the motto later in his autobiography (Hall, 1923, p. 447). Significantly, Hall was an admirer of German intellectual culture, having studied in Germany and having attended lectures by Wundt and Helmholtz (see, for example, Hall, 1881). As Henderikus Stam (personal communication) has noted, the motto - es gibt nichts Praktischeres als eine gute Theorie - has a long and 
somewhat unclear German heritage, being attributed to various nineteenth century scientists and, most significantly, to Kant. It is more than probable that Lewin, as a student of German philosophy, would have come across the saying.

To this day, German writers continue to attribute the aphorism to Kant, typically without citing a specific source: see, for instance Knischek’s book of philosophical quotations (2009, p. 207) and Krüger and Vogt's (2007) introductory chapter to their edited book on theories of biological education. The textbooks in social psychology do not hint that the motto might have a Kantian origin. Those readers who go on to become professional social psychologists can still believe that the discipline's supposed founder formulated the disciplinary motto. Even believing that the founder heard it spoken by a businessman would be preferable to accepting that the motto of their empirical discipline owes its origin to a non-empirical philosopher.

Absence of evidence. The social psychology textbooks, which quote the motto, not only fail to point to the longer history of the motto, but they demonstrate another absence: they do not refer to any empirical evidence to support the motto’s truth. This is an interesting absence since that the textbooks position social psychology as a science that empirically tests common sense. Likewise, handbooks and research papers, which cite the motto, do not provide supporting evidence (e.g., Taylor, 1998). It would not be difficult to design a study that operationalised good and bad theories and then tested whether practitioners tended to find good theories to be more practical for their purposes than bad ones. Given the many thousands of experiments that social psychologists have conducted over the years, one would suppose that any study empirically testing the motto (and, especially if finding supporting evidence) would have become widely cited. The absence of any referencing suggests that social psychologists have not seriously tested, let alone validated, their father's/founder’s motto. Reber and Beckstead (2009) describe the motto “a 
foundational premise of applied social psychology” (p. 151). It is if the motto has been placed beyond validation. Had it had been tested and found wanting, then much more than a saying would have been jeopardised.

When the textbooks quote the motto, they do not mention Lewin's ideas about good and not so good scientific theories. By championing mathematical Galileian science over probabilistic Aristotelian science, Lewin (1931/1999) was in effect justifying his own mathematised field theory, which practitioners have not found to be particularly useful (Burnes and Cooke, 2013). As such, Lewin’s own impractical “good theory” hardly supports his motto. On the other hand, the non-mathematical theories of current social psychology, which narrowly concentrate on the connections between a few variables, are not the sort of theories that Lewin had in mind as good theories. He imagined that a good theory would provide an alternative to ordinary language and that it would be used to explore single concrete occurrences in detail.

The resulting paradox should be clear. Social psychology textbooks justify their discipline by claiming that common sense needs the sort of empirical testing that social psychologists can provide. Yet the discipline has its own common sense beliefs, among which Lewin's motto occupies an important place. The discipline's members do not treat the motto as a hypothesis requiring validation. Its status is altogether different: it is a wise, absolute truth coming from the discipline's founder.

This can be seen in comments by Stroebe et al (2013) as they conclude their introductory chapter:

“Social psychology today is an exhilarating and thriving enterprise. Living up to Lewin's motto that nothing is as practical as a good theory, social psychologists are applying the understanding they have gained from their study of fundamental 
cognitive, emotional and motivational processes to the solution of real-life problems” (p. 22)

The tone is not that of neutral, scientific description but it resembles that of a CEO delivering an upbeat annual report on the "thriving enterprise" to shareholders. For the success of this rhetoric, it is vital that the motto, which the enterprise is said to be successfully fulfilling, is not presented as originating from an anonymous businessman, run-of-the-mill social psychologist or long dead philosopher. It is rhetorically much more powerful if the motto is seen to come from the founder of the thriving enterprise.

The writers are claiming that social psychologists are validating the motto because they are applying their understanding to the solution of social problems. Here we can note two subtle but significant shifts of emphasis. First, the original motto pointed to the importance of "good theory", rather than social psychological theory in general. Most current social psychological theories would, according to Lewin’s distinction between Galileian and Aristotelian theory, fail to count as good theories. In Stroebe et al's use of the motto, the notion of "good theory" (and its implicit contrast with bad theory) slips away. It is not just social psychologists producing good theories that are living up to the motto: it is “social psychologists” in general, as a community.

There is another shift which also upgrades the implied meaning of the motto: the shift from being practical to providing solutions. The original motto claimed that good theory was practical, but now social psychologists are said to be applying their understanding to the "solution” of (unspecified) social problems. Kassin, Fein and Markus (2011) are slightly more specific and slightly more qualified, when claiming that "built on the legacy of Kurt Lewin, social psychology contributes to the solution of numerous social problems, such as environmental degradation” (p. 14). 
As always, what is omitted can be as significant as what is mentioned. It is not just the absence of references: the writers do not identify which social psychological work is supposedly leading to the solution of social problems like environmental degradation. There is another absence: politics. It is implied that the problems will be solved when social psychological knowledge is applied. There is no sense that the problems might be political in origin and that they will require political solutions. There is certainly no suggestion that the understanding of social psychologists might also be, or even need to be, political. Instead, social psychology is presented as a neutral empirical science, producing an understanding which, if applied, will result in the solving of social problems.

Some of the textbooks recruit Lewin in order to convey that social psychology is inherently beneficial to the world: that experimentation and theory making, even when apparently abstruse and non-useful, are in fact contributing to the general good. In doing so, they omit the critical element in Lewin's use of the motto. When Lewin (1944) used the motto, he was criticising applied researchers who avoided theory and theorists who looked towards social problems with "highbrow aversion” (p. 27). Today’s textbooks tend to use the motto to suggest that theory and practice are naturally connected. Sanderson (2010) claims that the connection between theory and application is "inherent": "Kurt Lewin, the founder of modern social psychology, saw the inherent connection between social psychological theory and application as one of its greatest strengths; 'There is nothing so practical as a good theory’” (p. 11). Hogg and Vaughan (2011) use a different, but similar, adjective - “natural”. They write: “Much like Kurt Lewin’s view that there is nothing so practical as a good theory, our philosophy is that basic and applied research and theory are intertwined or best treated as intertwined: they are naturally interdependent” (p. 35). 
The adjectives "inherent” or "natural” put the matter beyond aspiration or empirical testing. The thriving existence of the discipline in itself validates the wise words of its founder. The circle is closed, but the meaning of the motto has been decisively altered. Moreover, the textbooks do not offer their student readers any way to check the present mythology about the discipline’s past that the textbooks are transmitting.

\section{Conclusions}

The adjectives "natural” and "inherent”, as used by the textbook writers in the above examples, suggest that we might be observing that part of the disciplinary common sense that could be called disciplinary ideology. According to some theorists, ideology functions to make the contingent world of human actions appear natural and immutable, as if beyond politics and vested interest (Eagleton, 1991; Ricoeur, 1986; Billig, 1991). Claiming the link between "good" theory and practice to be "natural” implies that the link does not depend on particular social and political contexts, or that there might be social, political conditions in which second-rate and even untrue theories might be more likely to be used practically (Billig, in press).

The critical discourse analyst Teun van Dijk (2009) writes that ideology refers to the shared fundamental, axiomatic beliefs of particular groups. Few social psychologists would challenge the quotations, which have been examined above, or would critically unpack the meanings of Lewin's much quoted motto. As such, experimental social psychology, whose rationale is based on a scientific critique of common sense, would seem to possess its own disciplinary common sense, communal memories and even ideological assumptions. 
Kurt Lewin derived the distinction between Aristotelian and Galileian science from his teacher, the philosopher Ernst Cassirer, although he deliberately ignored Cassirer's writings on psychology (Billig, in press). Cassirer (1953) argued that our human ability to create myths is integral to our capacity for language and, in consequence, even in the most scientific of times myth-making still retains a force. Cassirer's ideas on myth may be generally ignored by social psychologists, but they are instantiated within those textbooks that herald Lewin as the discipline's father/founder, while simplifying, even forgetting, his ideas. Such textbooks are re-creating Lewin as a mythic hero, not as a historical figure. Also, they treat his motto as if it were a magical phrase which, if uttered, will ward off disciplinary doubts.

References

Allport, G.W. (1948). The genius of Kurt Lewin. Journal of Social Issues, 4, 14-21.

Allport, G.W. (1954). The historical background of modern social psychology. In G. Lindzey (Ed.), Handbook of social psychology, vol. 1 (pp. 3-56). Reading, Mass.: AddisonWesley.

Aronson, E., Wilson, T.D. \& Akert, R.M. (2010). Social psychology, seventh edition. Boston: Pearson.

Ash, M.G. (1998). Gestalt psychology in German culture, 1890-1967. Cambridge, UK: Cambridge University Press.

Baron, R.A. \& Branscombe, N.R. (2013). Social psychology, thirteenth edition. Harlow, UK: Pearson. 
Biber, D. \& Conrad, S, (2009). Register, genre and style. Cambridge, UK: Cambridge University Press.

Biber, D. \& Gray, B. (2010). Challenging stereotypes about academic writing: Complexity, elaboration, explicitness. Journal of English for Academic Purposes, 9, 2-20.

Biber, D., Conrad, S. \& Cortes, V. (2004). If you look at...: Lexical bundles in university teaching and textbooks. Applied Linguistics, 25, 371-405

Billig, (1991). Ideology and opinions. London: Sage.

Billig, M. (2008a). The hidden roots of critical psychology. London: Sage.

Billig, M. (2008b). The language of critical discourse analysis: The case of nominalization. Discourse \& Society, 19, 783-800.

Billig, M. (2013). Learn to write badly: How to succeed in the social sciences. Cambridge, UK: Cambridge University Press.

Billig, M. (in press) Kurt Lewin's leadership studies and his legacy to social psychology: Is there nothing as practical as a good theory? Journal for the Theory of Social Behaviour.

Bordens, K.S. \& Horowitz, I.A. (2014). Social psychology, fourth edition. Solon, OH: Academic Media Solutions.

Burnes, B. \& Cooke, B. (2013). Kurt Lewin’s field theory: A review and re-evaluation. International Journal of Management Reviews, 15, 408-425.

Cassirer (1953). Language and myth. New York: Dover.

Crisp, R.J. \& Turner, R.H. (2014). Essential social psychology, third edition. London: Sage. 
Danziger, K. (1994). Constructing the subject. Cambridge, UK: Cambridge University Press.

Danziger, K. (2000). Making social psychology experimental: A conceptual history 19201970. Journal of the History of the Behavioral Sciences, 36, 329-347.

Delouvée, S., Kalampalikis, N. \& Pétard, J-P. (2011).There is nothing so practical as a good...history: Kurt Lewin’s place in the historical chapters. Estudios de Psychologia, 32, 243-255.

Eagleton, T. (1991). Ideology. London: Verso.

Elliott, A. (2008). Concepts of the self, second edition. Cambridge, UK: Polity Press.

Erll, A. (2011). Memory in culture. Basingstoke, UK: Palgrave Macmillan.

Farr, R.M. (1996). The roots of modern social psychology. Oxford, UK: Blackwell.

Fowler, R. (1991). Language in the news. London: Routledge.

Fowler, R., Hodge, B., Kress, G. \& Trew, T. (1979). Language and social control. London: Routledge.

Gergen, K.J. (2001). Social construction in context. London: Sage.

Gilovich, T., Keltner, D. \& Nisbett, R.E. (2011). Social psychology, second edition. New York, NY: W.W. Norton.

Haines, H. \& Vaughan, G.M. (1979). Was 1898 a 'great date' in the history of social psychology? Journal of the History of the Behavioral Sciences, 15, 323-332.

Halbwachs, M. (1992). On collective memory. Chicago: University of Chicago Press.

Hall, G.S. (1881). Aspects of German culture. Boston: James R. Osgood.

Hall, G.S. (1906). Youth: Its education, regimen and hygiene. New York: Appleton and Co. 
Hall, G.S. (1923). Life and confessions of a psychologist. New York: Appleton and Co.

Hogg, M.A. \& Abrams, D. (1988). Social identifications. London: Routledge.

Hogg, M.A. \& Vaughan, G.M. (2011). Social psychology, sixth edition. Harlow, UK: Pearson.

Hyland, K. (2005). Stance and engagement: A model of interaction in academic discourse. Discourse Studies, 7, 173-192.

Hyland, K. (2009). Academic discourse. London: Continuum.

Jahoda, G. (2013). A history of social psychology. Cambridge, UK: Cambridge University Press.

Kalampalikis, N., Delouvée, S. \& Pétard, Y. J-P. (2006). Historical spaces of social psychology. History of the Human Sciences, 19, 23-43.

Kaminski, J. (2011). Theory applied to informatics - Lewin’s Change Theory. Canadian Journal of Nursing Informatics, 6 (1). Retrieved from http://cjni.net/journal/?p=1210

Kassin, S., Fein, S. \& Markus, H.R. (2011). Social psychology. Belmont CA: Wadsworth.

Katz, D. (1979). Obituary: Floyd H. Allport (1890-1978). American Psychologist, 34, 351353.

Knischek, S. (2009). Lebensweisheiten berühmter Philosophen. Hannover, Germany: Humboldt.

Krüger, D. and Vogt, H. (2007). Es gibt nichts Praktischeres als eine gute Theorie. In D. Krüger and H. Vogt (Eds.), Theorien in der biologiedidaktischen Forschung (pp.1-7). Berlin, Germany: Springer Verlag. 
Levine, R. (2008). Introduction. In R. Levine, A. Rodrigues \& L. Zelezny (Eds.), Journeys in social psychology (pp. ix-xiii). Hove, UK: Psychology Press.

Lewin, K. (1931/1999). The conflict between Aristotelian and Galileian modes of thought in contemporary psychology. In M. Gold (Ed.), The complete social scientist: a Kurt Lewin reader (pp. 37-66). Washington, DC: American Psychological Association.

Lewin, K. (1938). Will and needs. In W.D. Ellis (Ed.), A source book of Gestalt psychology (pp. 283-299). London: Kegan Paul, French, Trubner.

Lewin, K. (1943/1999). Psychology and the process of group living. In M. Gold (Ed.), The complete social scientist: a Kurt Lewin reader (pp. 330-345). Washington, DC: American Psychological Association.

Lewin, K. (1944). Constructs in psychology and psychological ecology. University of Iowa Studies in Child Welfare, 20, 1-29.

Lewin, K. (1951/1999). Field theory in social science. In Resolving social conflicts and Field theory in social science. Washington, DC: American Psychological Association.

Lubek, I. (1993). Social psychology textbooks: an historical and social psychological analysis of conceptual filtering, consensus formation, career gatekeeping and conservatism in science. In H.J. Stam, L.P. Mos, W. Thorngate and B. Kaplan (eds), Recent trends in theoretical psychology, volume III (pp. 359-378). New York: Springer.

Lubek, I. (2000). Understanding and using the history of social psychology. Journal of the History of the Behavioral Sciences, 36, 319-328. 
MacMartin, C. \& Winston, A.S. (2000). The rhetoric of experimental social psychology, 1930-1960: from caution to enthusiasm. Journal of the History of the Behavioral Sciences, 36, 349-364.

Marrow, A.J. (1969). The practical theorist: The life and work of Kurt Lewin. New York: Basic Books.

McGraw, K. (2006). How and why psychology matters. In R.E. Goodwin \& C.E. Tilly (Eds.), Oxford Handbook of Contextual Political Analysis (pp. 131-156). Oxford, UK: Oxford University Press.

Middleton, D. \& Brown, S.D. (2005). The social psychology of experience. London: Sage.

Moscovici, S. \& Marková, I. (2006). The making of modern social psychology. Cambridge, UK: Polity.

Murphy, G \& Murphy, L.B. (1931). Experimental social psychology. New York: Harper and Brothers.

Murphy, G., Murphy, L.B. \& Newcomb, T. (1937). Experimental social psychology, revised edition. New York: Harper and Brothers.

Myers, D.G. (2008). Social psychology, ninth edition. Boston: McGraw-Hill.

Olick, J.K. (2007). Usable pasts and the return of the repressed. Hedgehog Review, 9(2), 1931.

Pandora, K. (1997). Rebels within the ranks. Cambridge, UK: Cambridge University Press.

Pelly, L. (2006). Romancing the vote. Athens, Georgia: Georgia University Press. 
Pétard, J.P., Kalampalikis, N. \& Delouvée, S. (2001). Les histoires de la psychologie sociale dans ses manuels. Cahiers Internationaux de Psychologie Sociale, 52, 59-80.

Rafferty, E.C. (2003). Apostle of human progress: Lester Frank Ward and American political thought. Lanham, MD: Rowman and Littlefield.

Reber, J.S. \& Beckstead, Z.B. (2009). Anti-reductionist empiricism in contemporary psychological research. In J.B. Clegg (Ed.), The observation of human systems (pp.141-161). New Brunswick, NJ: Transaction.

Ricoeur, P. (1986). Lectures on ideology and utopia. New York: Columbia University Press.

Rosenfeld, S. (2011). Common sense: A political history. Cambridge, Mass.: Harvard University Press.

Sanderson, C.A. (2010). Social psychology. Hoboken, NJ: John Wiley.

Skidelsky, E. (2009). Ernst Cassirer: The last philosopher of culture. Princeton, NJ: Princeton University Press.

Smyth, M.M. (2001). Fact making in psychology: The voice of the introductory textbook. Theory \& Psychology, 11, 609-36.

Stainton-Rogers, W. (2007). Social psychology, second edition. Maidenhead, UK: Open University Press.

Stam, H.J., Lubek, I. and Radtke, H.L. (1998). Repopulating social psychology texts: Disembodied ‘subjects’ and embodied subjectivity. In B.M. Bayer and J. Shotter (Eds.), Reconstructing the psychological subject, (pp. 153-186). London: Sage. 
Stam, H.J., Radtke, H.R. \& Lubek, I. (2000). Strains in experimental social psychology: A textual analysis of the development of experimentation in social psychology. Journal of the History of the Behavioral Sciences, 36, 365-382.

Stroebe, W., Hewstone, M. \& Jones, K. (2013). Introducing social psychology. In M. Hewstone, W. Stroebe \& K. Jones (Eds.), An introduction to social psychology, fifth edition (pp. 1-24). Oxford, UK: Blackwell.

Taylor, S.E. (1998). The social being in social psychology. In D. T. Gilbert, S.T. Fiske \& G. Lindzey (Eds.) Handbook of social psychology, vol. 1, fourth edition, (pp. 58-95). New York: Oxford University Press.

Taylor, S.E., Peplau, L.A. \& Sears, D.O. (2006). Social psychology, twelfth edition. London: Pearson.

Tileagă, C. \& Byford, J. (Eds.) (2014). Psychology and history. Cambridge, UK: Cambridge University Press.

van Dijk, T.A. (2009). Critical discourse studies: A sociocognitive approach. In R. Wodak and M. Meyer (Eds.), Methods of critical discourse analysis (pp. 62-86). London: Sage.

Weick, K. E. (2003). Theory and practice in the real world. In H. Tsoukas and C. Knudsen (Eds.), The Oxford handbook of organization theory (pp. 453-474). Oxford, UK: Oxford University Press. 
Author biography.

Michael Billig is Professor of Social Sciences at Loughborough University. He has published books on a number of different topics in social psychology, including rhetoric, psycho-analytic theory, nationalism, fascism and humour. His latest book, Learn to write badly (2013, Cambridge University Press), criticises the way that social scientists habitually write, arguing that their technical language is typically less clear and less precise than ordinary language.

Michael Billig, Department of Social Sciences, Loughborough University, Loughborough, Leicestershire, LE11 3TU, United Kingdom

m.g.billig@lboro.ac.uk 